\title{
Toxic chemical element barium content in different biosubstrates of children with congenital heart diseases
}

\author{
O Koval ${ }^{1 *}$, I Mokryk², N Nagorna', G Dubova', O Dudchak', V Volodyn², N Usenko', O Muzychyn², \\ A Nechiporchuk' ${ }^{2}$ A Novak ${ }^{2}$
}

From 23rd World Congress of the World Society of Cardio-Thoracic Surgeons Split, Croatia. 12-15 September 2013

\section{Background}

Number of studies indicates on possible role of toxic substances in development of heart malformations during cardiogenesis. The aim of our research is studying of toxic element barium content in different biosubstrates of children with CHD.

\section{Methods}

29 patients $(17(58,6 \%)$ boys and $12(41,6 \%)$ girls), aged from 14 days to 17 years (medium age: 26 month \pm 2 month) old with CHD were examined by the spectral analysis of toxic element barium in intraoperative (23) and autopsy (6) biopsies of endocardium (22), myocardium (26), pericardium (7), aorta (10), skin (8), subcutaneous fat (8), intercostal muscles (24), fascia (2), kidneys (5), brain (2) and hair (9) by methods of the atomic emission spectrometry in the inductively coupled plasma and atomic absorption spectrometry with electrothermal atomization.

\section{Results}

A comparative analysis of barium level in different biosubstrates demonstrated it's highest content (числа) in muscle tissue (myocardium, smooth muscle of the vessel walls, cross-striated rib muscles). Whereas in other tissues the concentration was decreased or absent. Barium content exceeded toxic level in heart tissues of $72.4 \%$ of patients. The excess degree of barium content depended on biopsy topics, namely, in aorta coarctation place, valve atresia place, septal defect its level was in two, ten or more times higher than in normal heart area or great vessel area.
Dependence between the barium excess degree content in the heart tissue and severity of malformation or its combinations was also established: children with exceeding level of barium in the heart tissues had significantly more ( $\mathrm{p}<0.05)$ of combined complex CHD.

\section{Conclusions}

Barium affinity to the myocardium, blood vessels smooth muscles and striated skeletal muscles was confirmed. Spectrum of barium content depends on the type and severity of the defect and biopsy point. Received data indicate on possible role of barium in cardiogenesis malformation, that needs deeper investigation.

\section{Authors' details}

'Pediatric Subdepartment of Internship and Postgraduate Education Faculty of Donetsk National Medical University n.a. M. Gorkiy, Donetsk, Ukraine. ${ }^{2}$ Department of Cardiosurgery, Cardiology and Rehabilitation for Children, Government Institution "Institute of Urgent and Recovery Surgery named after V. K. Gusak National Academy of Medical Science of Ukraine", Donetsk, Ukraine.

Published: 11 September 2013

\section{doi:10.1186/1749-8090-8-S1-0140}

Cite this article as: Koval et al:: Toxic chemical element barium content in different biosubstrates of children with congenital heart diseases. Journal of Cardiothoracic Surgery 2013 8(Suppl 1):0140.

\footnotetext{
* Correspondence: aleksandrakoval@ya.ru

'Pediatric Subdepartment of Internship and Postgraduate Education Faculty

of Donetsk National Medical University n.a. M. Gorkiy, Donetsk, Ukraine

Full list of author information is available at the end of the article
}

(c) 2013 Koval et al; licensee BioMed Central Ltd. This is an Open Access article distributed under the terms of the Creative Commons 